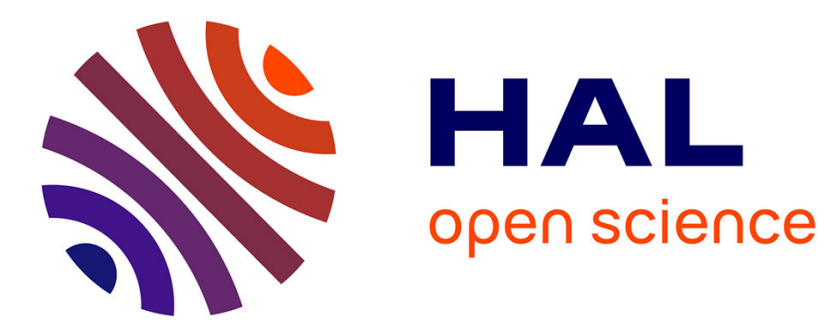

\title{
Examining Circular Economy Business Models for Engineer-to-Order Products
}

Nina Pereira Kvadsheim, Deodat Mwesiumo, Jan Emblemsvåg

\section{To cite this version:}

Nina Pereira Kvadsheim, Deodat Mwesiumo, Jan Emblemsvåg. Examining Circular Economy Business Models for Engineer-to-Order Products. IFIP International Conference on Advances in Production Management Systems (APMS), Sep 2019, Austin, TX, United States. pp.570-578, 10.1007/978-3030-30000-5_70. hal-02419208

\section{HAL Id: hal-02419208 \\ https://hal.inria.fr/hal-02419208}

Submitted on 19 Dec 2019

HAL is a multi-disciplinary open access archive for the deposit and dissemination of scientific research documents, whether they are published or not. The documents may come from teaching and research institutions in France or abroad, or from public or private research centers.
L'archive ouverte pluridisciplinaire HAL, est destinée au dépôt et à la diffusion de documents scientifiques de niveau recherche, publiés ou non, émanant des établissements d'enseignement et de recherche français ou étrangers, des laboratoires publics ou privés. 


\title{
Examining Circular Economy Business Models for Engineer-To-Order Products
}

\author{
Nina Pereira Kvadsheim ${ }^{1,2}$, Deodat Mwesiumo ${ }^{1,}$ and Jan Emblemsvåg ${ }^{2}$ \\ ${ }^{1}$ Møreforsking Molde, Britvegen 4, Molde, Norway; Nina.P.Kvadsheim@ @imolde.no; \\ Deodat.E.Mwesiumo@himolde.no \\ ${ }^{2}$ Molde University College, Britvegen 2, Molde, Norway; jan.emblemsvaag@nov.com
}

\begin{abstract}
Realization of the circular economy (CE) and its full potential requires firms to rethink their supply chains and business models. Although several frameworks in the literature propose circular economy business models (CEBMs) to redefine how companies create and capture value while adhering to CE principles, there has yet to be an examination of CEBMs in engineer to order (ETO) context. To address this gap, this study maximizes the depth of the phenomenon under investigation by leveraging a case study of a Norwegian company that deals with a large number of small ETO projects. Our findings increase knowledge of how ETO products can adapt to CEBMs.
\end{abstract}

Keywords: Circular Economy, Circular Economy Business Models, EngineerTo-Order Products.

\section{Introduction}

Victor Hugo's infamous quote, “you can resist an invading army; you cannot resist an idea whose time has come", is what possibly best encapsulates the concept of circular economy (CE) being the idea, that needs to replace the current production and consumption system - take-make-dispose linear model [1]. Most would agree that CE has become mainstream. It would be hard-pressed to find a firm that has not at least started a recycling initiative or engaged in some kind of community development project, even if the efforts were sparse. Auspiciously, many firms have gone far beyond, overhauling products and processes and looking outwards at system-wide innovation, and CE initiatives that promise to radically reshape their businesses now and in the future [2]. As more firms begin to recognize the potential of this novel approach, the CE quickly moves from theory to practice and the demand for businesses to embrace it strategically and operationally, and for the governments to establish a consistent set of rules for CE [3] is growing accordingly. More importantly, CE calls for novel business models that will simultaneously ensure the creation of environmental quality, economic prosperity, and social equity to benefit current and future generations [4]. This is understandable since a business model is the essence of a firm, representing the architecture through 
which firms create value, deliver value to their customers and capture value for themselves. Thus, if the role of the firm is vital for a successful transition to CE, then the implementation of new business models is warranted.

The extant literature addresses related topics, including a framework that integrates circular economy business models (CEBMs) and circular supply chain management [5], the development and application of a circular business experimentation framework [6], and a visualization tool to map CEBMs [7]. Although the literature provides useful insights, further research is still required on how firms can implement CE practices for value creation and capture [8]. This is crucial because $\mathrm{CE}$ implementation strategies are mainly associated with individual products [9]. As such, in this paper we use product as a unit of analysis when examining CE implementation strategies. Since CEBM implementation largely depends on individual products, with the assumption that varied products might require varied manufacturing plants, settings and strategies, and business models, the present study focuses on engineer-to-order (ETO) products. Against this backdrop, this study seeks to empirically identify the characteristics of specific ETO products and examine their appropriate CEBMs. To the best of our knowledge, no study has specifically investigated the CEBMs for ETO products and considering the uniqueness and relative complexity of ETO products, insights from this paper should be of interest to scholars, practitioners, and policy makers.

The paper proceeds as follows. We commence by reviewing literature related to CEBMs and production of ETO products. We then provide a framework that shows the general applicability of CEBMs for ETO products, which is followed by a methodology section and presentation of the case study. Finally, we discuss the findings and provide an outline for further work.

\section{Circular Economy Business Models (CEBMs)}

Before discussing CEBMs, it is important to understand the business model concept and its implications. A business model is defined as "the design or architecture of the value creation, delivery, and capture mechanisms [a firm] employs. The essence of a business model is in defining the manner by which the firm delivers value to customers, entices customers to pay for value, and converts those payments to profit"'[10]. In operational terms, a business model includes a value proposition (product and service; customer needs; geography), a revenue model (pricing logic; channels; customer interaction), and a cost model (core assets and capabilities; core activities; partner network). To be successful, these components must be coherent and internally aligned [11].

A CEBM can be defined as "the rationale of how an organization creates, delivers, and captures value with and within closed material loops" [12]. Studies on CE have addressed the design of CEBM in light of CE principles, and approaches to reconfigure and realign business model components according to CE practices [e.g., 8, 12]. Such models embrace cyclical material flows, renewable energy sources and cascading-type energy flows [13]. Put succinctly, to be regarded as 'circular', a model does not necessarily need to close material loops by itself within its own internal system boundaries; 
it could also be part of a larger system that together close a material loop echoing the Industrial Ecology thinking.

Studies by Stahel [14], and Bocken et al. [15], describe three key strategies for CE, from the resource perspective. 1) slowing loops, which extend a product's life to slow down resource usage (e.g. through repair); 2) closing loops between post-use and production through recycling, resulting in a circular flow of resources; and 3) narrowing loops, which aim to use fewer resources per product (e.g. through efficient manufacturing processes). Clearly, each of these strategies requires a different configuration of the value proposition, the revenue model, and the cost model, i.e., the business model. An intriguing question, then, is how to implement these for ETO products? Before addressing this question, the next section sets the scene by presenting ETO production.

\section{Production of ETO Products}

ETO refers to a strategy whereby design, engineering and production is based on specifications provided by a specific customer order. As such, the customer order's decoupling point for ETO is at the design stage such that each order is tied to the design phase of a product [16]. Given the product-process characteristics of this type of environment, the products are highly customized, produced in low volumes (often one-of-a-kind), and customer specific; also, the processes are labor intensive, usually non-repetitive, and often demand highly skilled labor [17]. The entire execution of the ETO product is often organized as a project particularly for capital goods. Since companies are generally unaware if and when a customer will place an order, accurately forecasting demand, ordering materials and producing products in advance are very challenging [18].

Drawing on Willner and colleagues' [19] ETO matrix, products can be produced using four ETO archetypes (complex, basic, repeatable, and non-competitive), depending on the number of units sold per customer order, the existence of repetitive customer orders and the engineering hours needed to produce the product. Given these four ETO archetypes, CE strategies for ETO products will plausibly vary according to the type of ETO production.

The subsequent section examines the appropriate CEBMs in ETO context.

\section{Examining appropriate CEBMs for ETO products}

CEBMs require the appropriate reconfiguration of value creation, delivery and capture, activities according to the nature/type of the product. We provide a framework, which shows the general applicability of CEBMs in ETO context (see Table 1). The framework proposes four major CEBMs for all ETO products (circular supplies, product life extension, product value extension and resource value). We further divide these major CEBMs into sub-CEBMs and describe them along four business model dimensions (value proposition, value delivery, value creation and value capture). This is derived from major frameworks such as business model canvas [20] and widely accepted conceptual analyses $[11,21]$. This alignment is essential in ensuring that ETO companies can understand and apply these CEBMs. 
Table 1. Circular Economy Business Models (CEBMs) and Circular Economy (CE) practices related to Engineer-To-Order (ETO) products. The highlighted rows $=$ major CEBMs

\begin{tabular}{|c|c|c|c|c|c|c|c|c|}
\hline \multirow[t]{3}{*}{ CEBMS } & \multicolumn{8}{|c|}{ CE practices related to ETO products } \\
\hline & \multicolumn{2}{|c|}{ Value proposition } & \multicolumn{2}{|c|}{ Value delivery } & \multicolumn{2}{|c|}{ Value capture } & \multicolumn{2}{|c|}{ Value creation } \\
\hline & Products & Services & Target Customer & \begin{tabular}{|l} 
Value delivery \\
Processes
\end{tabular} & Revenues & Costs & $\begin{array}{l}\text { Partners and } \\
\text { stakeholders }\end{array}$ & $\begin{array}{l}\text { Value creation } \\
\text { Processes }\end{array}$ \\
\hline \\
\hline $\begin{array}{l}\text { Industrial symbiosis (IS) } \\
{[15,22] \text {. }}\end{array}$ & \begin{tabular}{|l|} 
Waste as production \\
inputs
\end{tabular} & $\begin{array}{l}\text { Cost and supply risk } \\
\text { reductions; } \\
\text { synergistic } \\
\text { partnerships; third } \\
\text { party waste } \\
\text { reduction. }\end{array}$ & $\begin{array}{l}\text { Manufacturers; B2B } \\
\text { suppliers. }\end{array}$ & \begin{tabular}{|l} 
Sharing communal \\
services (e.g. \\
maintenance, \\
recycling); set up \\
geographically \\
proximate \\
collaborations (e.g. \\
eco-industrial parks).
\end{tabular} & $\begin{array}{l}\text { Additional revenues } \\
\text { through new IS } \\
\text { products/component } \\
\mathrm{s} ; \text { new revenue } \\
\text { potential through } \\
\text { green image. }\end{array}$ & \begin{tabular}{|l|} 
Reduction of waste \\
disposal costs; \\
reduction of material \\
and energy costs; \\
reduction of \\
transportation costs.
\end{tabular} & \begin{tabular}{|l|}
$\begin{array}{l}\text { Manufacturers; B2B } \\
\text { suppliers }\end{array}$ \\
\end{tabular} & $\begin{array}{l}\text { Physical exchange of } \\
\text { materials, energy, } \\
\text { water; sung own } \\
\text { waste and or third } \\
\text { party's as inputs for } \\
\text { production. }\end{array}$ \\
\hline \multicolumn{9}{|l|}{\begin{tabular}{|l} 
Product life extension \\
\end{tabular}} \\
\hline $\begin{array}{l}\text { Classic long-life model } \\
\text { [15]. }\end{array}$ & Long-lasting products & $\begin{array}{l}\text { Repair; maintenance; } \\
\text { upgrading }\end{array}$ & $\begin{array}{l}\text { B2B customers (Quality- } \\
\text { and cost-conscious) }\end{array}$ & $\begin{array}{l}\text { Offering long-lasting } \\
\text { products \& } \\
\text { corresponding repair/ } \\
\text { maintenance services; } \\
\text { uporading sercices }\end{array}$ & \begin{tabular}{|l|} 
Price premium for \\
longevity \& high \\
quality of products; \\
additional revenue \\
throung extended usager
\end{tabular} & $\begin{array}{l}\text { Long-term service \& } \\
\text { product warrantee cost }\end{array}$ & $\begin{array}{l}\text { After-sales service } \\
\text { agents. }\end{array}$ & $\begin{array}{l}\text { Designing long-lasting } \\
\text { products; repairing \& } \\
\text { upgrading of products } \\
\text { and/or components. }\end{array}$ \\
\hline \begin{tabular}{|l} 
Repair and maintenance \\
[24]/ Reuse \& \\
Redistribute [23].
\end{tabular} & $\begin{array}{l}\text { Repaired components; } \\
\text { spare parts; Reusablele } \\
\text { components parts. }\end{array}$ & $\begin{array}{l}\text { Securing uptime \& } \\
\text { lifespan of products; } \\
\text { shipping/installation; } \\
\text { maintenance; repair; } \\
\text { customer education; } \\
\text { facilitate collaboration. }\end{array}$ & \begin{tabular}{|l|} 
Quality-conscious (those \\
wwiling to pay more for \\
quality services); cost- \\
conscious customers (those \\
with constrained budgets)
\end{tabular} & $\begin{array}{l}\text { Providing (product- } \\
\text { based) services \& } \\
\text { results; Making reused } \\
\text { components accessible } \\
\text { \& affordable; take back } \\
\text { used components. }\end{array}$ & $\begin{array}{l}\text { Additional revenues } \\
\text { from the services } \\
\text { provided; additional } \\
\text { product or component } \\
\text { revenues. }\end{array}$ & $\begin{array}{l}\text { Reduction of material } \\
\text { costs (through } \\
\text { reusing repairing } \\
\text { components parts); } \\
\text { increase of labor and } \\
\text { logistics costs }\end{array}$ & $\begin{array}{l}\text { B2B customers } \\
\text { (shipyards \& } 8 \text { ship } \\
\text { owners); ; ffer-sales } \\
\text { service engineers; } \\
\text { manufacturers. }\end{array}$ & $\begin{array}{l}\text { Components upgrading } \\
\text { or upcycling; reselling } \\
\text { and or taking back } \\
\text { components } \\
\text { Maintaining or } \\
\text { repairing products \& } \\
\text { components }\end{array}$ \\
\hline \begin{tabular}{|l|}
$\begin{array}{l}\text { Refurbishment and } \\
\text { remanufacturing [24]. }\end{array}$ \\
remang
\end{tabular} & $\begin{array}{l}\text { Repaired, refurbished } \\
\text { products; used } \\
\text { components as inputs; } \\
\text { remanufactured } \\
\text { components; }\end{array}$ & $\begin{array}{l}\text { Upgrading; shipping } \\
\text { and installation, } \\
\text { warranties (auxiliary } \\
\text { services). }\end{array}$ & $\begin{array}{l}\text { Cost-conscious/B2B } \\
\text { customers; B2B suppliers. }\end{array}$ & \begin{tabular}{|l|}
$\begin{array}{l}\text { Providing used } \\
\text { components, materials; } \\
\text { taking back used } \\
\text { components. }\end{array}$ \\
\end{tabular} & $\begin{array}{l}\begin{array}{l}\text { Additional } \\
\text { productcomponent } \\
\text { revenues. }\end{array} \\
\end{array}$ & $\begin{array}{l}\text { Reduction of material } \\
\text { costs (through } \\
\text { upgrading); } \\
\text { transportation, } \\
\text { logistics. } \\
\end{array}$ & \begin{tabular}{|l|} 
B2B customers; \\
manufacturers; After- \\
sales service engineers.
\end{tabular} & $\begin{array}{l}\text { Restoring the } \\
\text { functionality of } \\
\text { components; upcycling } \\
\text { and taking back } \\
\text { components. }\end{array}$ \\
\hline \multicolumn{9}{|l|}{ Product va } \\
\hline \begin{tabular}{|l|} 
Extending product value \\
{$[15]$. }
\end{tabular} & $\begin{array}{l}\text { Used products or } \\
\text { components in as-new } \\
\text { quality; repaired } \\
\text { products. }\end{array}$ & $\begin{array}{l}\text { Taking back used } \\
\text { components. }\end{array}$ & B2B customers. & $\begin{array}{l}\text { Taking back used } \\
\text { components; selling } \\
\text { used components. }\end{array}$ & \begin{tabular}{|l} 
New revenue potential \\
from retaining material \\
ownership.
\end{tabular} & $\begin{array}{l}\text { Reduction of material } \\
\text { costs; increase of labor } \\
\text { and logistics costs. }\end{array}$ & \begin{tabular}{|l|} 
Collaborations with \\
B2B customers; after- \\
sales service engineers.
\end{tabular} & $\begin{array}{l}\text { Repairing or } \\
\text { remanufacturing own } \\
\text { components. }\end{array}$ \\
\hline $\begin{array}{l}\text { Product as a service [22]. } \\
\text { Pol }\end{array}$ & & $\begin{array}{l}\text { Leasing; renting; } \\
\text { product maintenance, } \\
\text { repair \& control. }\end{array}$ & B2B customers. & \begin{tabular}{|l|}
$\begin{array}{l}\text { Specifying } \\
\text { functionality, retaining } \\
\text { product ownership, }\end{array}$ \\
\end{tabular} & Leasing fee; rental fee. & $\begin{array}{l}\text { Product longevity; } \\
\text { product maintenance } \\
\text { costs; material costs } \\
\text { reduction. }\end{array}$ & $\begin{array}{l}\text { Manufacturers; B2B } \\
\text { suppliers; B2B } \\
\text { customers. }\end{array}$ & $\begin{array}{l}\text { Using products longer; } \\
\text { maintaining, repairing } \\
\& \text { controlling product. }\end{array}$ \\
\hline \multicolumn{9}{|l|}{\begin{tabular}{|l} 
Resource value \\
\end{tabular}} \\
\hline $\begin{array}{l}\text { Recycling and waste } \\
\text { management }[23,24] .\end{array}$ & \begin{tabular}{|l} 
Reusable/recyclable \\
production inputs; \\
components based on \\
recycled waste;
\end{tabular} & $\begin{array}{l}\text { Waste sorting; waste } \\
\text { recycling; take-back } \\
\text { management. }\end{array}$ & $\begin{array}{l}\text { Some key customers } \\
\text { (B2B) interested in using } \\
\text { such waste as production } \\
\text { input (downcycling) }\end{array}$ & \begin{tabular}{|l|} 
Providing used \\
components, materials, \\
waste; taking back used \\
components, waste.
\end{tabular} & \begin{tabular}{|l}
$\begin{array}{l}\text { Additional } \\
\text { productcomponent } \\
\text { revenues }\end{array}$ \\
\end{tabular} & \begin{tabular}{|l|} 
Waste handling \\
processing; resource \\
inputs; logistics; \\
transportation.
\end{tabular} & $\begin{array}{l}\begin{array}{l}\text { Key customers; } \\
\text { municipality }\end{array} \\
\text { (a) }\end{array}$ & $\begin{array}{l}\text { Components recycling; } \\
\text { upgrading or upcycling } \\
\text { of components; taking } \\
\text { back components. }\end{array}$ \\
\hline
\end{tabular}


'Circular supplies' are business models based on industrial symbiosis in which the residual outputs from one process can be used as feedstock for another [22]. Through it, ETO companies may replace linear resource approaches and phase out the use of scarce resources while reducing waste and removing inefficiencies. Whereas, 'product life extension' business models aim to extend the lifecycle of products through engineering solutions including repair, maintenance and/or upgrade [22, 23]. With this model, ETO companies can help ensure that products stay economically useful for as long as possible and that product upgrades are done in a more targeted way (e.g., fatigue/ obsolete components are replaced instead of the entire product). Moreover, 'product value extension' business models offer product access and retain ownership to internalize benefits of circular resource productivity [15]. This model would be attractive to a few ETO companies with high cost of operation for their products and that have skill advantage relative to their customers in maintaining the products, hence, giving them an advantage in selling services and recapturing residual value at end-of-life. 'Resource value' business models for these ETO products, is built on mostly 'recycling and waste management' [24], and generally, they can take different forms, thus, upcycling (which creates higher quality materials and improved functionality) and downcycling (e.g., the conversion of used materials into materials of lower value). This model is a good fit for most ETO companies especially where waste material from products can be reclaimed through take-back management and reprocessed cost effectively.

Nevertheless, for a CE to function these different types of CEBMs will need to interact and work together. For example, in the case of an advanced equipment to maritime industry, the 'product value extension' business model implies the equipment manufacturer either takes back used components of the products or retains ownership of the products, and is incentivized to repair/refurbish/upgrade the equipment over time to maintain maximum efficiency. However, the full circular benefit is only realized if the business models would allow for product and process design change, so that the products/components are repairable, upgradable and disassemblable to reduce the use of virgin materials [3]. Based on a CE, these ETO firms have the opportunity to expand their services they offer or collaborate with others to maximize value. For instance, a firm which bases their CEBM on refurbishing and remanufacturing their components may need to partner with a 'tracking facility' provider so they can monitor the whereabouts of their products, and then work with a logistics company or some of their B2B customers to ensure the end of life components are returned (take-back management).

Next, we present key methodological choices for the present study.

\section{$5 \quad$ Research methodology}

Our study explores an emerging phenomenon-CEBM, hence an embedded single-case design was deemed appropriate since single case design is suitable for revelatory purposes [25]. We selected a company (hereafter company X) that manufactures and supplies propulsion systems to shipyards and ship owners. With more than 1000 engineering hours per unit and 120 bespoke units sold annually, the propulsion system is a perfect example of an ETO product. We used three data collection approaches: face-to- 
face semi-structured interviews; direct, non-participant observation and document review. The next section describes company X and its ETO product characteristics, which are then matched with CEBMs identified in the developed framework.

\section{The case company, its ETO products and suitable CEBMs}

Company X's business concept is to design, manufacture, market and service complete systems for the propulsion, positioning and maneuvering of larger vessels. Products are highly customized, manufactured on-site, and are manifested through a project organized execution model covering engineering design, procurement and production, which are done in-house to ensure quality in integration of systems. Most of the equipment is designed to meet the demanding requirements of North Sea offshore standards and is used on different types of vessels (e.g. offshore, fishing, cruise, coast guard). In general, company $\mathrm{X}$ creates value by understanding customer requirements, translating them into specifications at the product and component levels, and integrating components and subsystems into products. Table 2 presents company X's ETO products characteristics and their descriptions.

Table 2. Company X's ETO product characteristics and their descriptions

\begin{tabular}{ll}
\hline $\begin{array}{l}\text { ETO product } \\
\text { characteristics }\end{array}$ & Description \\
\hline Low volume & $\begin{array}{l}\text { On average, 120 units are produced and sold annually. This varies sig- } \\
\text { nificantly year by year, depending on the condition of the market, etc. }\end{array}$ \\
\hline $\begin{array}{l}\text { High degree of } \\
\text { customization }\end{array}$ & $\begin{array}{l}\text { The products have high-engineering complexity (i.e. more than 1000 } \\
\text { hours per unit) and are engineered per precise customer specifications. }\end{array}$ \\
\hline $\begin{array}{l}\text { Project-based en- } \\
\text { vironment }\end{array}$ & $\begin{array}{l}\text { The ETO operations are typically project-oriented, thus, the customer is } \\
\text { exposed to the lead-time that encompasses the entire project duration. }\end{array}$ \\
\hline Product design & $\begin{array}{l}\text { Each product is engineered/designed according to specific require- } \\
\text { ments, which vary from one customer to another. }\end{array}$ \\
\hline $\begin{array}{l}\text { Customer in- } \\
\text { volvement/ Cus- } \\
\text { tomer specific }\end{array}$ & $\begin{array}{l}\text { Customer orders drive production. Each project is highly customer-spe- } \\
\text { cific and requires over 1000 engineering hours. The main drivers are } \\
\text { different propulsion system requirements, regulations imposed by class, } \\
\text { authorities and customer preferences (shipyards and ship owners). }\end{array}$ \\
\hline $\begin{array}{l}\text { Labor intensive/ } \\
\text { high-skilled labor }\end{array}$ & $\begin{array}{l}\text { Given the complexity of the products, the manufacturing process is la- } \\
\text { bor intensive and often demands highly skilled labor. }\end{array}$ \\
\hline $\begin{array}{l}\text { Type of modular- } \\
\text { ization }\end{array}$ & $\begin{array}{l}\text { There is a slight product modularization. Its design elements are split } \\
\text { up and assigned to modules based on a formal architecture or plan. }\end{array}$ \\
\hline
\end{tabular}

\section{Appropriate CEBMs for company $\mathbf{X}$}

From Table 1, we propose two major CEBMs that are appropriate for company X's propulsion systems: 'product life extension' (which builds on 'repair and maintenance', 'reuse and redistribute', and 'refurbishment and remanufacturing'), and 'resource value' (that builds on 'recycling and waste management').

'Repair and maintenance' business models are part of product sales and stand-alone services for company $\mathrm{X}$; they are more about offering superior product experiences and 
engaging customers in co-creation (e.g. following maintenance schedules), than they are about selling products [2]. These models are addressing almost all the business model dimensions, indicating how issues, such as customer-centric services, fast learning and problem-solving capabilities, and up-to-date product expertise, are essential and of high value to company $\mathrm{X}$. Since company $\mathrm{X}$ provides these services itself, there may a reduction in the costs for virgin materials.

Given the nature of the propulsion systems, 'reuse and redistribute' business model is the most relevant; there are only a few components and/or parts that are/can be reused. Instead of having used components flow (back) to company X directly or via an intermediary for repair and replacement, the company's aftersales service engineers typically decide whether components can be reused (whilst in the field with customers), depending on their level of wear or fatigue. The same applies to the 'refurbishment and remanufacturing' business models, which require that company $\mathrm{X}$ establishes the necessary reverse logistics to have access to used components [26]. It should be noted that, in this type of industry, buying back used components by contacting customers directly is challenging; it is extremely time-consuming to trace customers all over the world, and it is even harder to identify them after ship ownership changes. More so, buy-back method would involve high logistics costs. Since the products are located under the waterline, there is also the practical difficulties involved of obtaining the components except when the vessel is up for the 5-year class and maintenance dockings.

Considering 'recycling and waste management' business model, company $\mathrm{X}$ pays much attention to the downcycling of very few components such as electrical and electronic equipment. This is because recycling is quite challenging as most components have material grades and material mix adapted to the specific requirements, which over time changes due to technological improvements and most components degrade in seawater rendering them slowly less and less attractive for reuse or upcycling.

Put succinctly, these identified CEBMs would therefore allow company $\mathrm{X}$ greater control of their resource streams, innovation through the supply chain and enhanced collaboration within the supply chain amongst all actors.

\section{Conclusion and further work}

Most ETO manufacturers stand to benefit more from the multifarious collaborations that can be built based on these CEBMs and from component take-back to complex industrial symbiosis networks. CEBMs for ETO products mostly address one of the three key CE strategies: the slowing resource loops. There is, nonetheless, a need to convince manufacturers to adapt narrowing and closing loops strategies to retain product and material value, respectively, if they are to successfully transition to CE; to do so, companies must rethink their supply chains and how they create and deliver value. We have noticed that a recycling business model for ETO products is greatly underutilized partly due to the complexity of the product. Hence, further work may elucidate distinctly how ETO manufacturers should design a collection and recycling infrastructure for such a recycling business model, and how they may capture value from it. 


\section{$9 \quad$ References}

[1] M. Tonelli \& N. Cristoni, Strategic Management and CE. New York: Routledge, (2019).

[2] L. Clinton \& R. Whisnant, "Model Behavior: 20 Business Model Innovations for Sustainability," (2014).

[3] C. Guglielmo \& M. Nitesh, "Circular Business Models for the Built Environment," Arup BAM, pp. 1-44 (2017).

[4] J. Kirchherr, D. Reike, \& M. Hekkert, "Conceptualizing the circular economy: An analysis of 114 definitions," (2017).

[5] M. Geissdoerfer, S. N. Morioka, M. M. de Carvalho, \& S. Evans, "Business models and supply chains for the circular economy," J. Clean. Prod., 190, 712-721 (2018).

[6] N. M. P. Bocken, C. S. C. Schuit, \& C. Kraaijenhagen, "Experimenting with a CBM: Lessons from eight cases," Environ. Innov. Soc. Transitions, 28, 79-95 (2018).

[7] J. L. K. Nußholz, "A CBM mapping tool for creating value from prolonged product lifetime and closed material loops," J. Clean. Prod., 197, 185-194 (2018).

[8] E. Ünal, A. Urbinati, \& D. Chiaroni, "“Managerial practices for designing CEBMs: The case of an Italian SME in the office supply industry," J. Manuf. Technol. Manag. (2018).

[9] E. Ünal \& J. Shao, "A taxonomy of CE implementation strategies for manufacturing fi rms : Analysis of 391 cradle-to-cradle products," J. Clean. Prod., 212, 754-765 (2019).

[10] D. J. Teece, "Business models and dynamic capabilities," Long Range Plann., 51(1), 40-49 (2018).

[11] O. Schön, "Business Model Modularity -A Way to Gain Strategic Flexibility?," Control. Manag., 56(S2), 73-78 (2017).

[12] B. Mentink, "Circular Business Model Innovation:A process framework and a tool for business model innovation in a circular economy," (2014).

[13] J. Korhonen, A. Honkasalo, \& J. Seppälä, "Circular Economy: The Concept and its Limitations," Ecol. Econ., 143, 37-46 (2018).

[14] W. R. Stahel, "Circular economy," Nature, 531(7595) (2016).

[15] N. Bocken, I. de Pauw, C. Bakker, B. van der Grinten. "Product design and business model strategies for a circular economy," J. Ind. Prod. Eng., 1015, 1-12 (2016).

[16] J. Gosling \& M. M. Naim, "Engineer-to-order supply chain management: A literature review and research agenda," Int. J. Prod. Econ., 122(2) 741-754 (2009).

[17] D. Powell, J. O. Strandhagen, I. Tommelein, G. Ballard, \& M. Rossi, "A new set of principles for pursuing lean ideal in ETO," Procedia CIRP, 17, 571-576 (2014).

[18] J. W. M. Bertrand \& D. R. Muntslag, "Production control in engineer-to-order firms," Int. J. Prod. Econ., 30-31) 3-22 (1993).

[19] O. Willner, D. Powell, M. Gerschberger, \& P. Schönsleben, "Exploring the archetypes of ETO: an empirical analysis," Int. J. Oper. Prod. Manag., 36(3) 242-264 (2016).

[20] A. Osterwalder \& Y. Pigneur, Business Model Generation: A Handbook for Visionaries, Game Changers and Challengers, 30. New Jersey: John Wiley \& Sons, Inc., (2010).

[21] C. Zott, R. Amit, \& L. Massa, "The Business Model : Recent Developments and Future Research,” 37(4) 1019-1042 (2011).

[22] Accenture, "Circular Advantage: Innovative Business Models and Technologies to Create Value in a World without Limits to Growth," (2014).

[23] N. Kiørboe, H. Sramkova, \& M. Krarup, "Moving towards a circular economysuccessful Nordic business models," Copenhagen, (2015).

[24] P. Planing, "Business Model Innovation in a Circular Economy Reasons for NonAcceptance of Circular Business Models," no. April (2015).

[25] R. K. Yin, Case study research and applications: Design and methods, Sixth ed. USA: SAGE Publications, Inc., (2018).

[26] F. Ludeke-Freund, S. Gold, \& N. M. . Bocken, "A Review and Typology of Circular Economy Business Model Patterns,” J. Ind. Ecol.,00(0), 1-26 (2018). 